\title{
A STUDY OF HIBERNACULA AND HIBERNATING AS- SOCIATIONS OF SNAKES AND AMPHIBIANS IN MICHIGAN
}

\author{
Charles C. Carpenter \\ Department of Zoology, University of Michigan, Ann Arbor, Michigan
}

During the course of ecological studies of a garter snake population near Dixboro, Washtenaw County, Michigan from 1948 through 1951, many data were recorded on hibernating snakes. The 50acre area concerned surrounds and includes a button-bush marsh, with a mixed growth of sumac and grasses to the north and west, to the east a grazed pasture and to the south an oak-hickory wood lot. The grass-sumac area, which has a south-facing hillside with a flat area between it and the marsh, showed definite concentrations of snakes in the spring and fall.

\section{Ant Mound}

It was on this flat area that the first signs of hibernating activity were observed on October 6, 1948, when two recently born common garter snakes (Thamnophis s. sirtalis) were recorded near an abandoned ant mound. Subsequent observations definitely proved this mound to be a hibernaculum for a large number of individuals representing a variety of species of snakes and amphibians.

The circular ant mound, which was two feet in diameter and extended about six inches above the surrounding ground level, lay at the base of the gentle southfacing slope 75 feet from the marsh. Weeds, lichens, and mosses were growing on and about the mound. Numerous small entrances from $1 / 4$ to 1 inch in diameter led to small tunnels within the mound.

On three other occasions between the first observation and the following November 11, young-of-the-year common garter snakes and ribbon snakes (Thamnophis s. sauritus) were recorded sunning themselves at this ant mound. One of the common garter snakes had previously been recorded here.
The activity near this ant mound was followed throughout 1949, and during this period snakes were associated with it at least three times during the spring and three times in the fall. In the spring, 17. were ribbon snakes, one a common garter snake, one a Butler's garter snake (Thamnophis butleri) and one a Dekay's snake (Storeria dekayi). All had been born the previous summer. Those observed in the fall were: one adult common garter snake, one small common garter snake, one ribbon snake, one Butler's garter snake, and one smooth green snake (Opheodrys v. vernalis); all but the first were born during the summer.

This suggested that the small snakes were attracted to the structure. To obtain information on how many snakes and which species were using the ant mound as a hibernaculum, a confinement cage was devised to surround the mound so that the occupants could be captured and recorded as they emerged from beneath the ground. The confinement trap consisted of a cone of hardware cloth ( $1 / 8$ inch mesh) 3 feet in diameter at the base and 3 feet high. Six inches of the cone apex were cut off to facilitate free access of my hand to the interior to remove snakes. The base of the cone was reinforced with an inch-wide strip of sheet metal that was buried to a depth of 1 to 2 inches and packed solidly with dirt to prohibit animals from escaping. An outside fence, $2 \frac{1}{2}$ feet in height, was placed surrounding the cone trap. A small funnel entrance opened from this fence to the area between the fence and the cone. Snakes that approached or were returning to the mound and followed the circular fence would ultimately encounter the funnel opening. If an animal en- 
tered, its only escape was through the 1 inch opening at the inside end of the funnel which was 2 inches above the ground level. With these traps most, if not all, vertebrate occupants of the ant mound were recorded when they came to the surface and remained there, and any trend for snakes to re-enter would be indicated.

The confinement trap was placed over the ant mound early in March of 1950 before the ground had begun to thaw. Prior to this on January 3, during an unusually warm spell, two ribbon snakes (born summer before) were observed sunning at this mound and were marked and released into the mound tunnels. The trap remained over the mound until mid-July to insure the capture of all the vertebrates present. The results of this trapping procedure are listed in Table I.

The first 10 snakes captured in the confinement trap were recorded and again released within the cone to test whether there was another exit from the mound. All of these were again taken from the trap, most of them within three days, but two, three weeks later. All other snakes taken from the cone trap were released three feet east of the mound. None returned to be captured in the funnel trap surrounding the cone trap, although five other adult snakes were captured there.

The period of emergence from hiberna- tion was quite extended, from March 27 until May 30. Vetas (1951) indicates a spread of emergence from early April to late May for a den of striped racers (Masticophis t. taeniatus) and Great Basin rattlesnakes (Crotalus viridis lutosus) in Utah. Observations on activity near the ant mound also showed an extensive period of entrance into the hibernaculum.

All snakes, representing five species, were either young of the previous summer (1949), or juveniles, i.e., young from the summer of 1948. An adult striped chorus frog (Pseudacris nigrita triseriata) and a small Jefferson's salamander (Ambystoma jeffersonianum) were also recorded. In the fall of 1950 , after the trap had been removed, snakes were recorded at the mound on two separate occasions. On October 25, one common garter snake, two ribbon snakes, and one Butler's garter snake were sunning, and on November 1, one common garter snake and one Dekay's snake were observed. All had been born during this summer.

The ant mound was excavated on February 25,1951 . The digging was done very slowly with a trowel so that accurate data on position, depth, cloacal temperatures, and other features that might prove to be pertinent to hibernation in poikilotherms could be gathered. Digging was stopped at 30 inches because of darkness.

TABLE I. Dates of emergence of snakes and amphibians from an ant mound near Dixboro, Washtenaw County, Michigan, 1950

\begin{tabular}{|c|c|c|c|c|c|c|c|c|c|c|c|c|c|c|c|}
\hline \multirow{3}{*}{ Species } & \multicolumn{14}{|c|}{ Date of emergence } & \multirow{3}{*}{$\begin{array}{c}\text { Species } \\
\text { total }\end{array}$} \\
\hline & & \multicolumn{6}{|c|}{ April } & \multicolumn{6}{|c|}{ May } & \\
\hline & 27 & 30 & 3 & 7 & 15 & 16 & 16 & 28 & 2 & 3 & 10 & 16 & 24 & 31 & \\
\hline $\begin{array}{l}\text { Common garter snake } \\
\text { Ribbon snake } \\
\text { Butler's garter snake } \\
\text { Common water snake } \\
\text { Smooth green snake } \\
\text { Dekay's snake } \\
\text { Jefferson's salamander } \\
\text { Chorus frog }\end{array}$ & $\begin{array}{l}6 \\
1 \\
3\end{array}$ & $\begin{array}{l}4 \\
1\end{array}$ & $\begin{array}{l}7 \\
2 \\
5\end{array}$ & . & $\begin{array}{l}2(1 \mathrm{~J}) \\
1(\mathrm{~J})\end{array}$ & $\begin{array}{l}4(1 \mathrm{~J}) \\
2\end{array}$ & $\begin{array}{l}3(1 \mathrm{~J}) \\
2\end{array}$ & $\begin{array}{l}1 \\
1\end{array}$ & $\begin{array}{l}7(1 \mathrm{~J}) \\
3 \\
2 \\
1(\mathrm{~J})\end{array}$ & 4 & $\begin{array}{l}2 \\
2\end{array}$ & 1 & 5 & 1 & $\begin{array}{l}41(4 \mathrm{~J}) \\
4(1 \mathrm{~J}) \\
25 \\
2 \\
2(1 \mathrm{~J}) \\
1 \\
1 \\
1\end{array}$ \\
\hline
\end{tabular}

$\mathrm{J}=$ juvenile snakes born summer of 1948 , all other snakes born summer of 1949 . 
TABLE II. Species of snakes and amphibians recorded at various depths in an excavated ant mound, Washtenaw Co., Mich., Feb. 25, 1951

\begin{tabular}{|c|c|c|c|c|c|c|c|c|c|c|c|c|c|c|}
\hline \multirow[b]{2}{*}{ Species } & \multicolumn{13}{|c|}{ Depth (inches) } & \multirow[b]{2}{*}{$\begin{array}{l}\text { Specie } \\
\text { totals }\end{array}$} \\
\hline & $0-5^{*}$ & $6-7$ & $8-9$ & $10-11$ & $12-13$ & $14-15$ & $16-17 * *$ & $\begin{array}{c}18- \\
19\end{array}$ & $\begin{array}{c}20- \\
21\end{array}$ & $\begin{array}{c}22- \\
23\end{array}$ & $\begin{array}{c}24- \\
25\end{array}$ & $\begin{array}{c}26- \\
27 \\
\end{array}$ & $\begin{array}{c}28- \\
29\end{array}$ & \\
\hline Common garter snake & & $1\left(3^{\circ}\right)$ & & $2\left(5.8^{\circ}\right)$ & $4\left(3.4^{\circ}\right)$ & & $1\left(1.5^{\circ}\right)$ & 4 & 6 & 2 & & $\overline{1(J)}$ & 1 & 26 \\
\hline $\begin{array}{l}\text { Ribbon snake } \\
\text { Butler's garter snake } \\
\text { Common water snake } \\
\text { Smooth green snake }\end{array}$ & $\begin{array}{l}3(1 \mathrm{D}) \\
1(\mathrm{D})\end{array}$ & $\sqrt{2}$ & $1\left(5.6^{\circ}\right)$ & $1(D)$ & $3\left(5.8^{\circ}\right)$ & $\begin{array}{c}3\left(5.4^{\circ}\right) \\
1\end{array}$ & & & $\begin{array}{c}1 \\
7 \\
2 \\
1\left(4^{\circ}\right)\end{array}$ & 3 & 2 & 2 & & $\begin{array}{r}11 \\
15 \\
4 \\
1\end{array}$ \\
\hline $\begin{array}{l}\text { DeKay's snake } \\
\text { Red-bellied snake } \\
\text { Unidentified snake } \\
\text { Jefferson's salamander } \\
\text { Chorus frog } \\
\text { American toad }\end{array}$ & & $1 \mathrm{~T}$ & $\begin{array}{c}2\left(9.5^{\circ}\right) \\
2\end{array}$ & $\begin{array}{l}1 \\
1\end{array}$ & $1(\mathrm{D})$ & $\begin{array}{c}2\left(10^{\circ}\right) \\
3\end{array}$ & & 1 & $\begin{array}{l}3 \\
2\end{array}$ & & & & & $\begin{array}{l}2 \\
2 \\
1 \\
5 \\
9 \\
1\end{array}$ \\
\hline
\end{tabular}

$\mathrm{J}=$ juveniles born summer 1949 (all other snakes born summer 1950).

$\mathrm{D}=$ dead.

$\mathrm{T}=$ transformed summer 1950 .

$*$ = soil temperature $1^{\circ} \mathrm{C}$.

** $=$ soil temperature $2^{\circ} \mathrm{C}$.

Numbers in parentheses are individual or average cloacal temperatures (Centigrade).

The tunnels continued to go deeper and it is possible that there were more occupants present. The hibernaculum tunnels were interconnecting and while only 8 openings were found before excavating the mound, 18 separate tunnels were counted at a depth of 6 inches. The tunnels spread out underground so that the diameter of the area at one foot of depth was about three feet. This exceeded the original dimension of the mound above ground by one foot. The lower tunnels in this clay soil were very damp and many of the lowest ones reached were flooded. It is very possible that the snakes in the lowest tunnels were submerged in water.

Of the 77 vertebrates taken from the mound, 62 were snakes representing 7 species, and 15 were amphibians of 3 species. The numbers, depth at which found, and cloacal temperatures (taken of only a few) are shown in Table II. Many slugs, earthworms, ants, crickets, beetles and sow bugs were taken from all depths of the tunnels.

The six-inch portion of the mound that protruded above the ground level had a dead ribbon snake (born summer of 1951), which appeared to have been frozen. Otherwise, the first living records were for two ribbon snakes two in- ches below the ground level, eight inches beneath the upper surface of the mound. The common water snake ( $\mathrm{Na}$ trix s. sipedon) that was found at 10 inches was in a state of decay and the cause of death could not be determined. Most specimens were very sluggish, but did have the ability to move and flick their tongues when prodded.

There is a tendency for one species to average higher or lower than another. With respect to the ribbon snake and Butler's garter snake at the ant mound, this difference was noticed in two ways. First, in the spring of 1945 , the ribbon snakes were the first to appear near the mound and they also appeared here later in the fall than Butler's garter snakes. In 1950, all of the ribbon snakes had emerged by April 15, but Butler's garter snakes continued to emerge until May 24. Second, this may be correlated with the respective positions of these two species in the excavated mound. The ribbon snakes averaged higher in the tunnels than Butler's garter snakcs. Because of the shape of many of these tunnels, it would not be possible for many of the individuals in the lowest tunnels to emerge until those above them had moved out. The difference between the times of emergence 
from hibernation, at least for those two species, may be related to their depth in the hibernaculum. Further work should be done to see if this is correlated with temperature tolerance. The amphibians were generally scattered at all levels.

The body positions in which the hibernating snakes were found varied considerably. These variations may have been the result in some instances of the shape, size, and direction of the tunnels. Of those animals stretched out full length in the tunnels, some had their head at the upper end and others at the lower end of the tunnels. Some individuals were doubled once, with the head either higher, level with, or lower than the rest of the body. About one-half of the snakes were slightly coiled, the others were fully extended. The striped chorus frogs were in level tunnels, while the Jefferson's salamanders were headed both up and down. These vertebrates were not coiled together in masses but were scattered throughout the tunnels. Two individuals were frequently together in a small tunnel, in various combinations of the species represented.

The cloacal temperatures of the snakes show that the temperature is generally above that of the surrounding environment and that deeper snakes have a slightly higher cloacal temperature than those nearer the surface. That some of these snakes were above the frost line and had survived at this level seems certain, but a few nearer the surface may have been killed by severe cold. Bailey (1949) has shown that Thamnophis radix may survive sub-freezing temperatures up to 28 days. I have recorded many cloacal temperatures of snakes during cold weather which were higher than those of their environment. Lueth (1941) observed that at low temperatures, the body temperature of a snake is above that of its environment.

Of the snakes taken from the ant mound, eight had previously been captured and marked. Four had been marked late in the fall of 1950. These included a com- mon garter snake, marked at the mound, two Butler's garter snakes, one captured 50 feet from the mound and the other 5 feet from the mound, and a Dekay's snake marked at the mound. All had been born the preceding summer. The other four had been trapped by the confinement trap as they emerged from the ant mound in the spring of 1950 . Three were common garter snakes, and the other was a smooth green snake. All had been born during the summer of 1949 , and were the only snakes of this age group taken from the mound. All others were one year younger. One of the common garter snakes was recorded on October $31,1950,176$ feet east of the hibernaculum.

The ant mound was used as a hibernation site by young snakes and small amphibians from 1948 to 1950 and probably had been used for some time before this and would have continued to be used had it not been excavated. The den studies of Woodbury (1951) and his students were followed for 10 seasons. They had many returns of individuals year after year. In my study, by the following fall most small snakes at the ant mound had grown to a size that would generally prohibit them from entering the small tunnels, and this was presumably the reason that more of them did not return year after year.

\section{Meadow Vole Tunnel}

On March 28, 1949, a few days after the first snakes emerged from hibernation, 15 small snakes, all born the previous summer, were captured in a few minutes' time within a small area of approximately 100 square feet ( 800 feet east of the ant mound). They represented 4 species of which 11 were ribbon snakes, two common garter snakes, one Butler's garter snake and one common water snake. All had presumably been hibernating near by and were sunning themelves. A hibernaculum was found later in this area.

On January 2, 1950, a warm winter day $\left(8.5^{\circ} \mathrm{C}\right.$. $)$, while looking for sunning snakes on this same area, the head of a 
small ribbon snake was noticed disappearing down a small hole about one inch in diameter. As the entrance of this tunnel was opened, the tail of a snake was seen 6 inches down. Between this depth and the end of the deepest tunnel at 15 inches, 16 snakes of 6 species and 3 amphibians of 2 species were removed. They were as follows: $\mathbf{3}$ adult common garter snakes and one adult Dekay's snake; two common garter snakes, five ribbon snakes, one Butler's garter snake, three common water snakes, and one smooth green snake, all young of the summer of 1949 . The amphibians removed were two Jefferson's salamanders and one striped chorus frog.

About one-third of the snakes were coiled together at the eight-inch level where the tunnel widened to form a small chamber. This group contained the frog and salamanders as well as young and adult snakes. The rest of the snakes were scattered singly and stretched out in small tunnels down to the lowest depth observed. This underground chamber appeared to be that of a meadow vole ( $\mathrm{Mi}$ crotus pennsylvanicus) and had two runways just beneath the surface, one running 10 feet west and the other 3 feet north. The snakes were located in such a manner that it would not have been possible for the lower snakes to emerge until those above had moved out. All the snakes were marked, returned to the excavated cavity, and covered to simulate as closely as possible the conditions under which they had been found. When this cavity was opened again late in the spring, only the decayed remains of a single garter snake were present. One of the marked snakes was captured about a year later showing that it, at least, had survived.

\section{Crayfish Burrow}

When snakes were observed in the spring and the late fall near the openings of tunnels, these points were recorded for future investigation. One such hole, a crayfish burrow, which had a large garter snake near it early in the spring of 1950 , was checked on February 24, 1951. The crayfish burrow was located at the base of a six-foot hawthorn bush on the flat area between the south-facing grass-sumac hill and the marsh. The ground was still frozen in many places and this particular hole was plugged with ice. The removal of the first piece of sod around the hole revealed a snake in a small cavity partially filled with water. The water level was three inches below the surface of the ground. The snake started to move farther back into the cavity, which extended a short distance around the roots of the bush. The technique followed was to dig out and follow down the hole with a trowel, reaching ahead of the digging as far as possible to capture any animals present. Table III gives the results of this procedure.

TABLE III. Results of excavation of flooded crayfish burrow used as snake hibernaculum, Washtenaw Co., Mich., Feb. 24, 1951

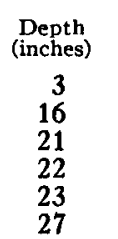

$\begin{array}{lc}\text { Species } & \begin{array}{c}\text { Cloacal } \\ \text { temperatur } \\ \left({ }^{\circ} \mathrm{C} .\right)\end{array} \\ \text { Common garter snake } & 4.2 \\ \text { Common garter snake } & 3.4 \\ \text { Common garter snake } & 5.0 \\ \text { Common water snake } & 7.0 \\ \text { Burrowing crayfish } & \\ \text { Common garter snake } & 6.8\end{array}$

The tunnel had a number of bends, and these, plus the very cold water $\left(2^{\circ} \mathrm{C}\right.$. when first opened) and the hard clay soil made the digging difficult. Since the water in the burrow would flow higher when an arm was thrust down, a side trench was constructed to drain it off. This trench soon filled up, indicating that the water level was just beneath the ground surface. The cloacal temperatures were taken as soon as the snakes were removed from the hole. Digging was stopped at 35 inches because this was as far down as the shoulder and arm could reach. The diameter of the burrow varied from $1 \frac{1}{2}$ to 2 inches. At least the lower four snakes must have been totally submerged in the water and the deepest snake recorded was below the burrowing crayfish (Cambarus diogenes), the probable builder of this hibernaculum. Of the five snakes removed, 
all were adults, 3 males and 2 females, four of which had been marked previously during the warm seasons.

On January 3, 1950, an adult common garter snake was observed sunning, and while this individual was being captured two adult common water snakes were found about one foot away. By searching closely in the grass at this area an opening to a burrow was revealed. This tunnel was completely flooded. While taking notes and watching this hole, the front part of a snake's head appeared above the water. As it emerged and became aware of my presence, it withdrew into the burrow leaving only its nose out of the water. On reaching to capture it, it went deeper beyond the reach of my fingers. A few minutes later, when I returned, a very wet and muddy common garter snake was next to this entrance, presumably the same snake that had emerged during my short absence. I later placed a small confinement cage over this opening, and on April 4, 1950 a small adult common water snake had emerged from the burrow through a small celluloid trap door placed over the entrance and was attempting to escape. Excavation of this burrow in February 1951 proved it to be that of a crayfish, but no snakes were found down to a depth of three feet. The tunnel was also flooded at this time.

Approximately four feet from the burrow just mentioned were two similarly flooded holes. As I was about to turn my attention from these, a movement was noticed in one of them, and a few seconds later a striped chorus frog emerged from beneath the water. One of these frogs had also been found near the hole previously mentioned.

The findings presented indicate very strongly that many snakes hibernate completely submerged in water in underground tunnels. It seems that this should be possible provided the water is very cold. Turtles and frogs regularly hibernate at the bottoms of pools and small lakes. The soil where the hibernacula studied were located consisted of a hard clay with very little organic material.
Pope (1937) mentions a common water snake being taken from beneath five inches of water in a spring in western New York state. The water temperature was about $60^{\circ} \mathrm{F}$.

\section{Predation}

Evidence indicating that snakes hibernating in crayfish burrows may be preyed upon by the crustaceans was gathered on a number of occasions. On January 2, 1950 while passing the opening of a crayfish burrow, the tail of a garter snake was noticed down in the tunnel. When this snake was removed, another snake could be felt deeper in the hole. Both snakes were adult Thamnophis and had most of the head and fore-part of the body destroyed as if they had been fed upon. Whether these snakes had been killed by the crayfish is not certain, but their presence in the burrow probably indicates that they were eaten by the crayfish.

On February 24, 1951 the remains of two snakes were found next to the entrance of a crayfish burrow. The remains of one was only a skeleton, but the other showed evidence of having been fed upon. The rotting remnants of a Dekay's snake were found at the ice-plugged entrance of another such burrow on March 3, 1951. On December 12, 1949, a dead adult common garter snake was found half-way out of a crayfish burrow, but it showed no evidence of having been fed upon.

Under warm conditions an adult snake would not be ready prey for a crayfish, but in the torpid state of hibernation they would be easy prey.

On November 2, 1948, an adult common water snake was located in what probably was its hibernaculum. It was uncovered about one inch beneath the leaf litter at the base of a bush thicket near the top of a wooded hill, 15 feet above water level and 40 feet from the marsh. It was coiled beneath the damp leaves and was very sluggish. There was lose dirt beneath the leaves and numerous tunnels led into the base of the bushes. Adult common water snakes in this area were 
seldom seen outside the marsh except in the late fall. One fall an adult male was observed coiled on a large rock on a hillside in the woods about 30 feet from the marsh, and another was captured crawling through dense grass down a ravine about 40 feet from the marsh. This activity would indicate that some individuals of this species may move away from the marsh to higher ground to hibernate.

\section{Discussion}

The places used as hibernacula are structures that have been made by animals other than the reptiles and amphibians using them for winter dens. This suggests that there may be a close relationship between the abundance of these poikilotherms and the available hibernation sites.

The dens observed were near the marsh at ground level close to the water table and not up on the hillside in the better drained soils. This may be related to the necessity of moisture for successful hibernation, because low temperatures quickly dehydrate. It is well known that frogs and turtles hibernate under water, but this is not generally known to be true of snakes. The evidence gathered here suggests that at least the common water snake and the common garter snake may hibernate completely submerged. It has often been suggested that snakes recorded as active in winter and others found active early in the spring have been "flooded out" of hibernation. It seems more likely that the warm rains penetrate down to hibernating forms and this warmth stimulates them to become active.

It is not uncommon to find a number of species or a large number of individual snakes using the same hibernaculum (Woodbury 1951; Gloyd 1944; Pope 1937), but seven species of snakes associated with salamanders, frogs, and a toad is an unusual association. Criddle (1937) records taking 8 Thamnophis radix, 101 Storeria occipito-maculata, and 148 Opheodrys $v$. vernalis from an ant hill in Manitoba. The amphibians recorded from the Michigan regions are the normal food of the snakes during warmer seasons, and an association at this time would certainly not be of any benefit to the amphibians. They are evidently attracted by similar requirements for hibernation sites during the fall after feeding has ceased and move out from hibernation before the snakes are actively feeding in the spring.

\section{SUM MARY}

A number of hibernacula including an ant mound, crayfish burrows, and a vole tunnel were studied in Washtenaw County, Michigan. The following species of snakes and amphibians were found associated on excavation of these structures: Thamnophis s. sirtalis, Thamnophis $s$. sauritus, Thamnophis butleri, Natrix s. sipedon, Opheodrys $v$. vernalis, Storeria dekayi, Storeria occipitomaculata, Ambystoma jeffersonianum, Pseudacris nigrita triseriata, and Bufo a, americanus. Evidence gathered from the excavations indicates that snakes may hibernate submerged completely beneath water. Cloacal temperatures of snakes were higher than those of the surrounding environments. Some variation of preferred hibernating depth, perhaps related to time of emergence, was indicated. Burrowing crayfish may prey upon snakes hibernating in their burrows. A confinement trap was used in studying emergence from the ant mound.

\section{REFERENCES}

Bailey, R. M. 1949. Temperature toleration of garter snakes in hibernation. Ecology, 30: $238-242$.

Criddle, Stuart. 1937. Snakes from an ant hill. Copeia, 1937 : 142.

Gloyd, H. K. 1944. The problem of too many snakes. Chicago Naturalist, 7: 87-97.

Lueth, F. X. 1941. Effects of temperature on snakes Copeia, 1941: 125-132.

Pope, C. H. 1937. Snakes alive, and how they live. 238 pp. New York: Viking Press.

Vetas, Basil. 1951. [Symposium: A snake den in Tooele County, Utah] Temperatures of entrance and emergence. Herpetologica, 7: 15-19.

Woodbury, A. M. 1951. [Symposium: A snake den in Tooele County, Utah] Introduction-a ten year study. Herpetologica, 7: 4-14. 